\title{
SUPPLEMENTATION OF S-ALLYL CYSTEINE IMPROVES HEALTH SPAN IN Caenorhabditis elegans
}

\author{
A SUPLEMENTAÇÃO DE S-ALIL CISTEÍNA MELHORA A DURAÇÃO DA SAÚDE \\ EM Caenorhabditis elegans
}

\author{
Jun-Sung KIM ${ }^{1}$; Sang-Kyu PARK ${ }^{2}$ \\ 1. Graduate student, Department of Medical Sciences, Soonchunhyang University, Asan, Chungnam, Korea; 2. Associate \\ Professor, Department of Medical Biotechnology, Soonchunhyang University, Asan, Chungnam, Korea. skpark@sch.ac.kr
}

\begin{abstract}
Previous studies show that nutritional interventions with anti-oxidants have various healthpromoting effects in several model organisms. Here, we examine the effects of S-allyl cysteine on resistance to environmental stressors and age-related physiological changes using $C$. elegans as a model system. S-allyl cysteine is a modified amino acid found in aged garlic extracts and known to have strong anti-oxidant activity. The survival of worms under oxidative-stress conditions significantly increased with supplementation of S-allyl cysteine. In addition, pretreatment of S-allyl cysteine significantly increased resistance to both heat stress and ultraviolet irradiation. However, lifespan was not affected by S-allyl cysteine treatment. We also examined the effect of S-allyl cysteine on motility of $C$. elegans and found that S-allyl cysteine can retard the age-related decline of muscle tissue locomotive activity. S-allyl cysteine also significantly suppressed amyloid $\beta$-induced paralysis in Alzheimer's disease model animals. Taken together, our study indicates that dietary supplementation of S-allyl cysteine can improve health span and suggests that S-allyl cysteine can be used to develop novel health-promoting pharmaceuticals.
\end{abstract}

KEYWORDS: S-allyl cycteine. C. elegans. Health span. Motility. A $\beta$-toxicity.

\section{INTRODUCTION}

S-allyl cysteine (SAC) is an organosulfur compound found in aged garlic. In addition to SAC, aged garlic extracts contain allin, cycloallin, $\mathrm{S}$ methyl cysteine, $\beta$-chlorogenin, and among others (ALLISON et al., 2006). Aged garlic extracts possess many pharmaco-therapeutic properties, including anti-oxidant, anti-allergic, anti-cancer, neuro-protective, and hepato-protective activities (COLIN-GONZALEZ et al., 2015; MORIHARA et al., 2006). SAC is the most abundant compound in aged garlic and has strong anti-oxidant activity (COLIN-GONZALEZ et al., 2015). At the cellular level, reactive oxygen species (ROS), including superoxide radical and hydrogen peroxide $\left(\mathrm{H}_{2} \mathrm{O}_{2}\right)$, are reduced by SAC treatment (IDE; LAU, 2001; MALDONADO et al., 2003). SAC can scavenge superoxide radical and reduce hydrogen peroxide production (COLIN-GONZALEZ et al., 2012; MEDINA-CAMPO et al., 2007). A recent study suggests that the underlying mechanisms of SAC anti-oxidant activity involves the induction of Nrf2 protein, a transcription factor modulating expressions of many anti-oxidant genes, both in vitro and in vivo in mice (SHI et al., 2015). In $C$. elegans, the effect of SAC is dependent on SKN-1, a worm homolog of Nrf-2, and independent on DAF-16 (OGAWA et al., 2016). Oxidative stress caused by ROS is considered one of major causal factors of many neurodegenerative diseases. In rats, supplementation of SAC reduces amyloid beta $(A \beta)$ induced oxidative damage in the brain and improves cognitive function (PEREZ-SEVERIANO et al., 2004). The neuroprotective effect of SAC is further supported by a decrease in $A \beta$-induced apoptosis in hippocampal neurons (PENG et al., 2002).

A number of studies have shown that dietary intervention with anti-oxidants has healthpromoting effects in various model organisms. Supplementation of resveratrol, a polyphenol compound contained in red wine, gives various health benefits, such as mitigation of neurodegeneration, carcinogenesis and atherosclerosis (FERGUSON, 2001; JANG et al., 1997). Cognitive impairment observed in aged animals is prevented by vitamin E supplementation in rats and dogs (FUKUI et al., 2002; MILGRAM et al., 2002). Curcumin or green tea polyphenol metabolites are effective in preventing ageassociated disorders, including cancer and atherosclerosis in mice (KITANI et al., 2004). The increased oxidant production and oxidative DNA damage are opposed by $\alpha$-lipoic acid supplementation (SUH et al., 2001). Coenzyme $\mathrm{Q}_{10}$ promotes the recovery of heart tissue after aerobic stress and the contractile function after cardiac surgery (ROSENFELDT et al., 2002). A recent study reports that $\mathrm{N}$-acetyl cysteine (NAC), a cysteine derivative having a strong anti-oxidant activity, can improve health span by increasing 
resistance to oxidative, heat, and ultraviolet (UV) stresses (OH et al., 2015).

Caenorhabditis elegans (C. elegans) is a widely used animal model for the screening of compounds or natural extracts expected to have health-promoting properties due to its relative short life cycle and lifespan, large brood size, and most importantly, high homology with the human genome. Comparative proteomic study reveals that at least $83 \%$ of $C$. elegans genes has human homologs (Lai et al., 2000). In the present study, we intend to reveal the effects of SAC supplementation on responses to environmental stressors and agerelated physiological changes, in vivo, using $C$. elegans as a model system.

\section{MATERIALS AND METHODS}

\section{Worm strains and maintenance}

The N2 CGCb strain purchased from the C. elegans Genetics Center (CGC, Minneapolis, USA) was used as wild-type control. The Alzheimer's disease model strain expressing human $\mathrm{A} \beta_{1-42}$ in muscle, CL4176 (dvls27 [myo3/A $31-42 /$ let UTR, rol-6]), was also purchased from CGC (Minneapolis, USA). Nematode growth media (NGM) containing $25 \mathrm{mM} \mathrm{NaCl}, 1.7 \%$ agar, $2.5 \mathrm{mg} / \mathrm{ml}$ peptone, $5 \mu \mathrm{g} / \mathrm{mL}$ cholesterol, 1

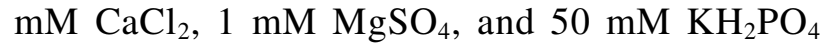
(pH6.0), was used as growth media. All experiments were conducted at $20^{\circ} \mathrm{C}$, unless the specific temperature shift was mentioned. Escherichia coli OP50 was added to each NGM plate as a food source.

\section{Survival under oxidative stress}

Five L4/young adult worms were transferred to a fresh NGM plate and permitted to lay eggs for $5 \mathrm{~h}$ at $20^{\circ} \mathrm{C}$. After removing the five adult worms, the progeny were grown at $20^{\circ} \mathrm{C}$ for 3 days. Age-synchronized worms were treated with different concentrations of SAC $(0,1$, $5,10 \mu \mathrm{M}$ ) for $24 \mathrm{~h}$. Then, the worms were exposed to $2 \mathrm{mM} \mathrm{H}_{2} \mathrm{O}_{2}$ in S-basal without cholesterol $(5.85 \mathrm{~g}$ sodium chloride, $1 \mathrm{~g}$ potassium phosphate dibasic, and $6 \mathrm{~g}$ potassium phosphate monobasic for 11 sterilized distilled-water). The survival of worms under oxidative-stress conditions was monitored at 2, 4, and $6 \mathrm{~h}$. A worm not responding to any mechanical stimuli was considered dead. Three independent repetitive experiments were performed. Statistical significance was measured using the standard two-tailed Student's t-test. A p-value lower than 0.05 was considered significant.

\section{Response to heat stress}

Sixty age-synchronized worms were treated with different concentrations of SAC on NGM plates for $24 \mathrm{~h}$ as previously mentioned and heat shock was administered to the worms by placing the plates in a $35^{\circ} \mathrm{C}$ incubator for $10 \mathrm{~h}$. Then, the worms were transferred back to $20^{\circ} \mathrm{C}$ and the number of dead worms was counted after $24 \mathrm{~h}$. We replicated the independent experiments three times.

\section{Resistance to UV irradiation}

Age-synchronized worms were cultured in NGM plates containing $5 \mu \mathrm{M}$ SAC for $24 \mathrm{~h}$ and exposed to $20 \mathrm{~J} / \mathrm{cm}^{2} / \mathrm{min}$ UV for $1 \mathrm{~min}$ in a $254 \mathrm{~nm}$ UV crosslinker (BLX-254, VILBER Lourmat Co., Torcy, France). After UV irradiation, the plates were transferred back to the $20^{\circ} \mathrm{C}$ incubator. Living and dead worms were scored every hour until all worms were dead. The experiments were repeated twice. We employed the log-rank test to analyze the data. The log-rank test is a non-parametric MantelCox test, widely used to compare two time-course survival curves (PETO; PETO, 1972).

\section{Lifespan assay}

Sixty age-synchronized 3-day-old worms were transferred to fresh NGM plates containing 5 $\mu \mathrm{M}$ SAC and 5-fluoro-2'-deoxyruridine to prevent internal hatching. Thereafter, worms were transferred to fresh NGM plates with the $5 \mu \mathrm{M}$ SAC and 5-fluoro-2'-deoxyruridine every other day until all worms were dead. The number of living and dead worms was scored every day. Three independent replicative experiments were performed. Statistical analysis was performed using the log-rank test (PETO; PETO, 1972).

\section{Locomotion assay}

The effects of SAC on age-related motility change was examined in age-synchronized worms $(n=100)$. Each worm's response to mechanical stimuli was monitored and recorded at 5, 10, 15, and 20 days after hatching. A worm that moved spontaneously without mechanical stimuli was grouped as "level 1". Worms that moved their whole body or only head after worm picker stimulation were recorded as "level 2" or "level 3", respectively. Dead worms were considered animals not responding to any mechanical stimuli. The experiments were repeated twice.

\section{Paralysis assay using human A $\beta$ transgene}

Age-synchronized young adult worms laid eggs for $2 \mathrm{~h}$ at $15^{\circ} \mathrm{C}$. Then, adult worms were 
removed from the plates. The plates containing only eggs were incubated at $25^{\circ} \mathrm{C}$ to induce the human $\mathrm{A} \beta$ transgene. After $18-20 \mathrm{~h}$ of induction, the number of worms paralyzed were scored every hour until all worms were paralyzed. We repeated the experiments three times.

\section{RESULTS AND DISCUSSION}

\section{SAC increases resistance to oxidative stress}

In order to evaluate the effects of SAC on environmental stressors response, we first examined the SAC supplementation on resistance to oxidative stress. Oxidative stress induced by $\mathrm{H}_{2} \mathrm{O}_{2}$, an innate ROS produced by cellular metabolism, resulted in decreased survival in untreated wild-type control (Fig. 1). However, worms pre-treated with SAC reduced susceptibility to oxidative stress. Among three different concentrations tested, $5 \mu \mathrm{M}$ of SAC significantly increased resistance to oxidative stress. After $2 \mathrm{~h}$ under oxidative-stress conditions, $45.6 \pm$ $17.88 \%$ (mean of three independent experiments \pm SEM) of worms survived in the wild-type control group and $86.7 \pm 5.09 \%$ of worms were still alive in SAC-treated worms. The percent survival decreased to $12.2 \pm 4.84 \%$ in the control, whereas $33.3 \pm$ $12.02 \%$ of SAC-treated worms survived after $4 \mathrm{~h}$.
KIM, J-S.; PARK; S-K.

The effect of SAC on survival under oxidativestress conditions increased from $2.2 \pm 2.22 \%$ in control to $23.3 \pm 1.92 \%$ after $6 \mathrm{~h}(p=0.002)$ (Fig. 1). The supplementation with 1 or $10 \mu \mathrm{M}$ of SAC failed to show a significant increase in resistance to oxidative stress in all time points tested $(p>0.05)$. These findings indicate that dietary supplementation with $5 \mu \mathrm{M}$ SAC can confer increased resistance to oxidative stress in $C$. elegans. Nutritional intervention studies using anti-oxidants have shown that there is a consistent correlation between dietary supplementation of anti-oxidants and response to oxidative stress. Polyphenol compounds found in red wine and green tea increase resistance to oxidative stress (KITANI et al., 2004; WOOD et al., 2004). Extracts from Acanthopanax sessiliflorus stem shows a suppressive effect on oxidative DNA damage and increased survival under oxidativestress conditions (PARK et al., 2014). Interestingly, $\mathrm{NAC}$, the other cysteine derivative, has strong antioxidant activity in vivo and induces the expression of anti-oxidant gene (OH et al., 2015). Therefore, further studies should focus on revealing underlying cellular mechanisms involved in increased resistance to oxidative stress by these cysteine derivatives.

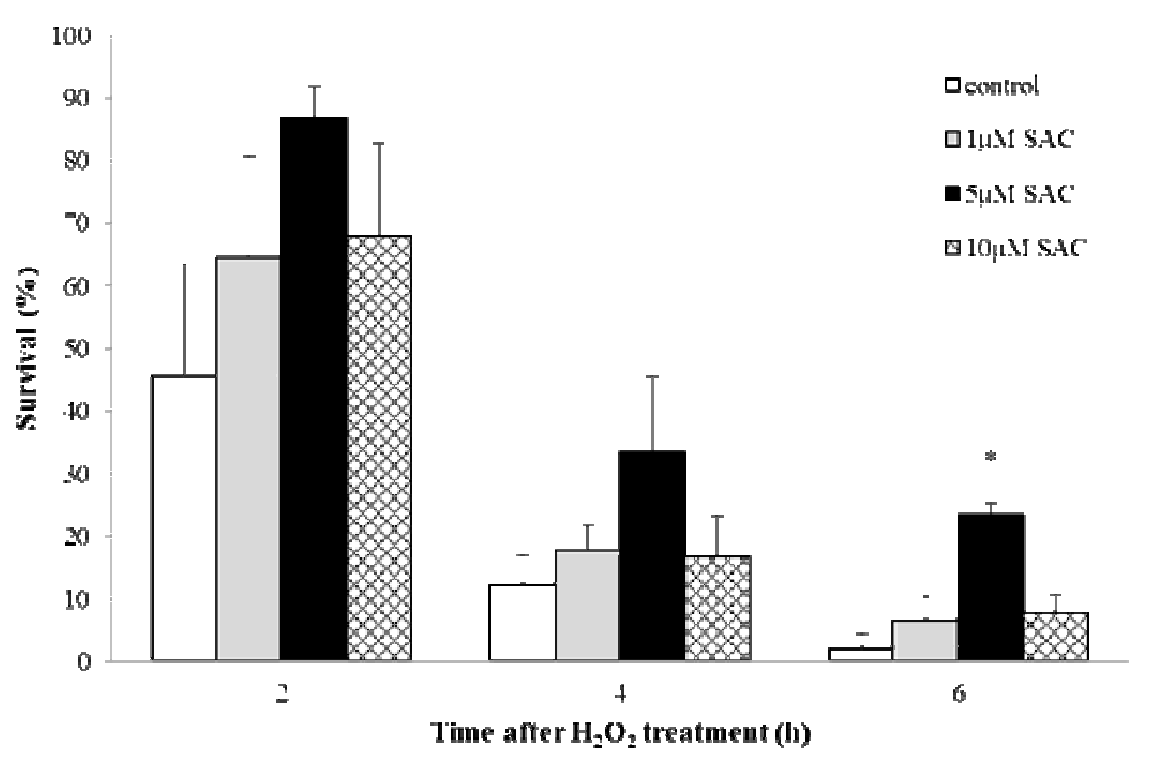

Figure 1. Increased resistance to oxidative stress by SAC. Oxidative stress was induced by treatment of $2 \mathrm{mM}$ $\mathrm{H}_{2} \mathrm{O}_{2}$. The effect of different SAC concentrations on survival under oxidative-stress conditions was monitored at 2, 4, and $6 \mathrm{~h}$ after $\mathrm{H}_{2} \mathrm{O}_{2}$ addition. Pre-treatment of $5 \mu \mathrm{M}$ SAC significantly increased survival of worms after $6 \mathrm{~h}$ of oxidative stress. The values are mean of three independent experiments. Asterisk indicates a statistically significant difference between control and SACtreated worms. 


\section{Effects of SAC on response to heat stress and UV irradiation}

Having observed increased survival under oxidative-stress conditions by SAC, we next determined the effect of SAC supplementation on other environmental stressors responses, including heat stress and UV irradiation. In the untreated wildtype control group, $59.0 \pm 3.09 \%$ of worms survived after $10 \mathrm{~h}$ of heat shock (Fig. 2). Treatment of different concentrations of SAC before heat shock increased survival after heat stress. As observed in response to oxidative stress, $5 \mu \mathrm{M}$ of SAC was the most effective concentration among three concentrations tested. The survival of worms treated with $5 \mu \mathrm{M}$ of SAC was increased up to $82.2 \pm$ $4.09 \%(p=0.010)$ (Fig. 2). The percent survival observed in worms supplemented with 1 and $10 \mu \mathrm{M}$ of SAC was also slightly increased up to $72.3 \pm 5.30$ and $79.3 \pm 7.89 \%$, respectively, but failed to show a statistically significant difference $(p>0.05)$. Based on previous results, we examined the effects of SAC on UV irradiation with $5 \mu \mathrm{M}$ of SAC. Supplementation of SAC significantly increased survival after UV irradiation $(p<0.001)$. Mean survival time was 4.7 and $6.2 \mathrm{~h}$ in the wild-type control and SAC-treated worms, respectively (Fig. $3 A$ ). There was a $31.8 \%$ increase in mean survival
KIM, J-S.; PARK; S-K.

time by SAC supplementation. The curve area was increased from 321.9 to 472.0 by SAC supplementation. Independent repeated experiments also showed significant increases in resistance to UV irradiation. There was an $11.2 \%$ increase in mean survival time and curve area was increased from 296.6 to 346.7 by SAC supplementation ( $p=$ 0.033) (Fig. 3B). Many studies have shown that increased resistance to oxidative stress accompanies increased survival under other environmental stressors. Worms grown in media prepared with electrolyzed-reduced water have increased resistance to oxidative stress and survive longer under heat stress or UV irradiation (PARK et al., 2012; PARK; PARK, 2013). Mutations in age-1 confer reduced susceptibility to both oxidative and heat stress (LARSEN, 1993). The supplementation of NAC modulates response to heat stress, in addition to oxidative stress. Increased survival after heat shock and induction of the $h s p-16.2$ gene is observed with NAC treatment (OH et al., 2015). Similar to our observation with SAC, worms with NAC supplementation also survive longer after UV irradiation ( $\mathrm{OH}$ et al., 2015). Taken together, we conclude that SAC has a strong bioactivity modulating response to various environmental stressors.

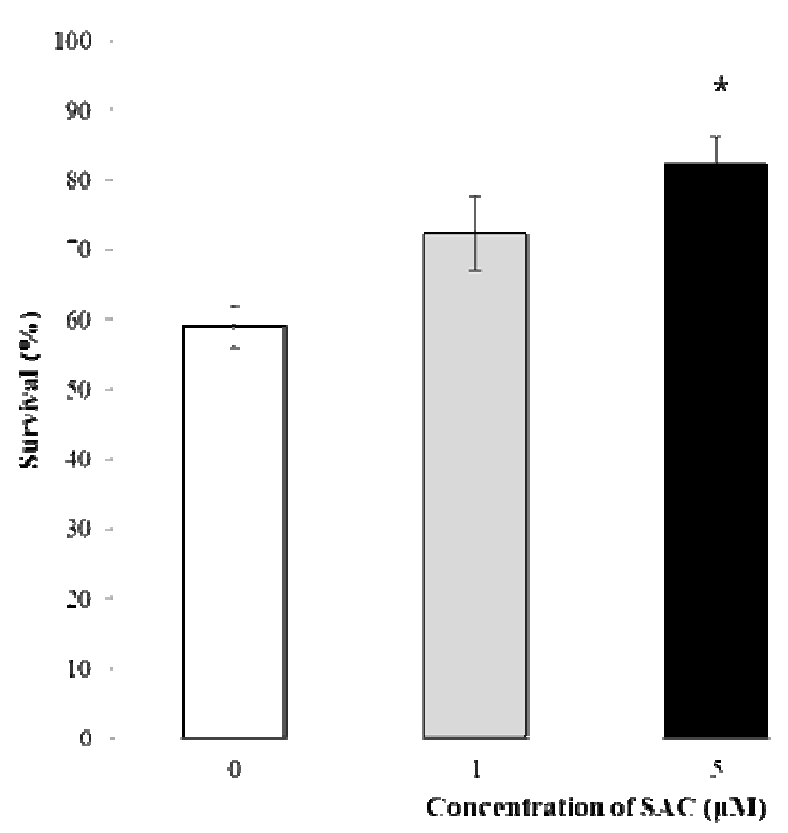

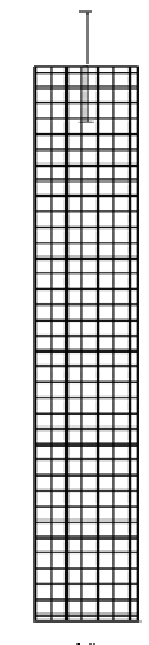

10

Figure 2. Effects of SAC on thermotolerance. Survival of worms after $10 \mathrm{~h}$ of heat shock was compared between the wild-type control and SAC-treated worms. Among different concentrations of SAC tested, only $5 \mu \mathrm{M}$ SAC conferred extended survival after heat shock. The values are mean of three independent experiments. Asterisk indicates a statistically significant difference between the control and SAC-treated worms. 
A

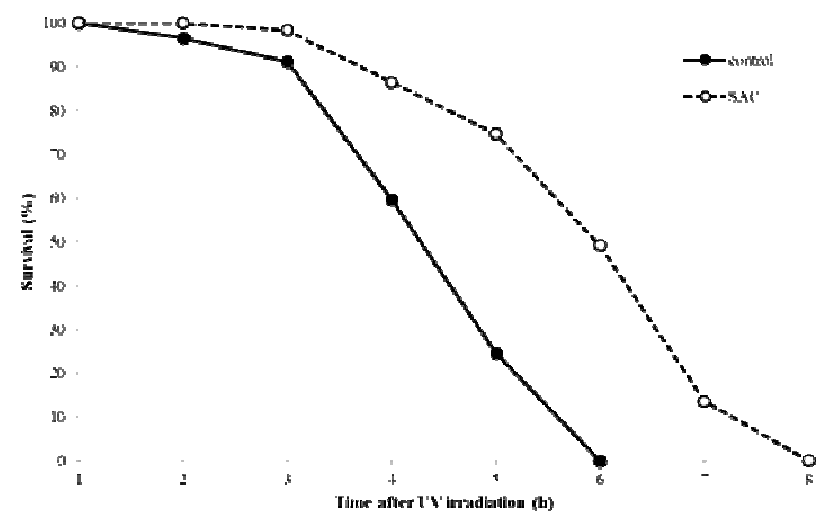

\section{B}

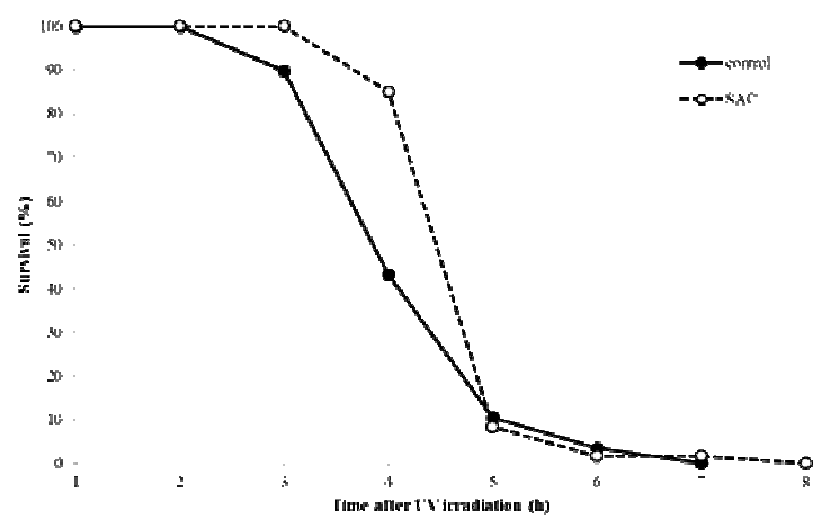

Figure 3. Extended survival after UV irradiation by SAC. The effect of $5 \mu \mathrm{M}$ SAC, which showed an increased resistance to oxidative and heat stress, on response to UV stress was determined twice (A and B). Both mean and maximum survival time was significantly extended by SAC treatment $(p<0.05)$.

\section{SAC treatment has no effect on lifespan}

The free radical theory of aging suggests that oxidative damage caused by free radicals is a major causal factor of normal aging (HERMAN, 1956). The most abundant free radicals found in cells are ROS produced as byproducts of cellular metabolism. Since we observed increased resistance to oxidative stress by the supplementation of SAC, we asked whether dietary intervention with SAC could extend C. elegans' lifespan. As shown in Fig. 4 , there is no significant difference in both mean and maximum lifespan between the untreated wild-type control and SAC-treated worms. Three independent experiments failed to show a significant effect on lifespan by SAC (data not shown). On the contrary, a recent study reports that higher concentrations of SAC, 10 and $100 \mu \mathrm{M}$, can extend mean lifespan upto 17.0 and $15.6 \%$, respectively (OGAWA et al., 2016). The effect of dietary anti-oxidants on lifespan is very complicated in various model organisms. For example, resveratrol or myricetin significantly extends the lifespan of $C$. elegans, while SOD/catalase mimetics show a controversial effect on lifespan (BAYNE; SOHAL, 2002; GRUNZ et al., 2012; WOOD et al., 2004). In mice, the supplementation of vitamin $\mathrm{E}$ or curcumin results in a longevity phenotype, whereas dietary intervention with coenzyme $\mathrm{Q}_{10}$ or $\alpha$-lipoic acid has no effect on lifespan (KITANI et al., 2004; LEE et al., 2002; NAVARRO et al., 2005). The effect of dietary anti-oxidants on lifespan seems to be variable depending on anti-oxidant molecules and model organisms, which causes controversy in authenticity of the free radical theory of aging. Interestingly, a previous study reveals that NAC has a lifespan-extending effect in C. elegans $(\mathrm{OH}$ et al., 2015). Therefore, it is assumed that different chemical modifications added on cysteine may cause different effects on lifespan. A recent study reports that NAC pre-treatment can cause reduced stress by inducing mitochondrial hormesis (SINGH et al., 2015). Increasing evidence indicates that low dose of ROS can work as a signaling molecule causing an adaptive response, such as mitohormesis, and rather increase lifespan (RISTOW et al., 2014). 


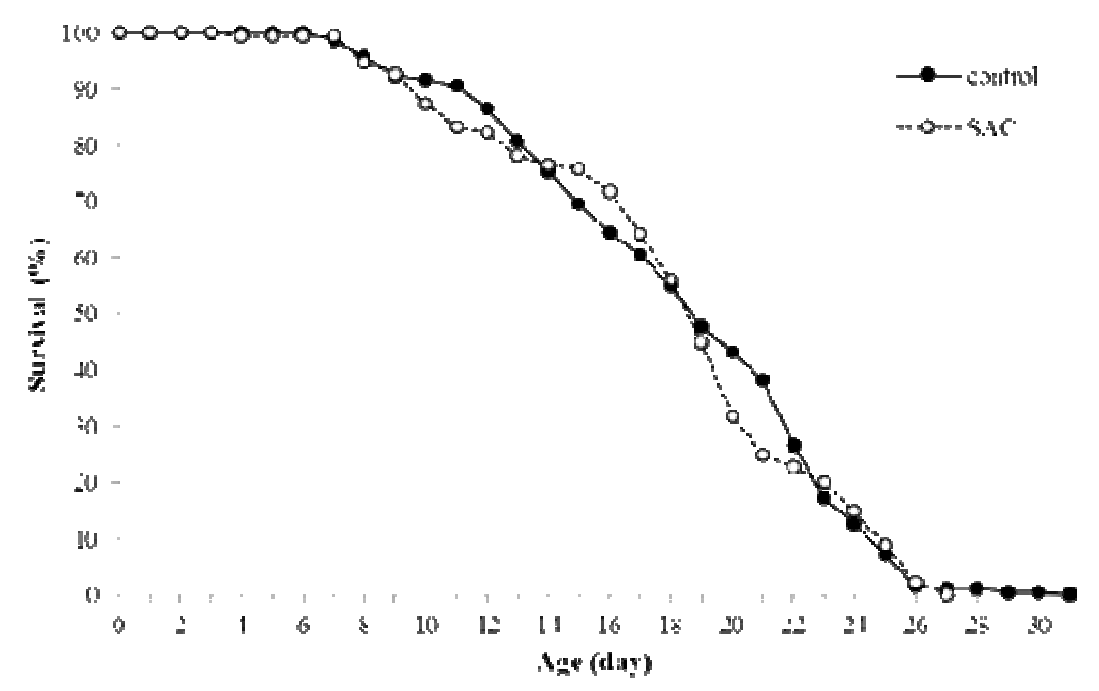

Figure 4. Effects of SAC on lifespan in C. elegans. Age-synchronized worms were counted every day until all worms died to evaluate the effects of SAC on C. elegans longevity. There is no significant difference in either mean or maximum lifespan between the wild-type control and $5 \mu \mathrm{M}$ SAC-treated worms. The values are mean of three independent experiments.

\section{SAC delays age-related motility decline}

Aging phenotypes in multicellular organisms are tissue-specific. Muscle is one of most vulnerable tissues to age-related accumulation of ROS, due to its high demand on mitochondrial energy metabolism. Based on the in vivo antioxidant activity of SAC, we measured the effects of SAC supplementation on motility change with normal aging. At the age of 10 days, $70.6 \pm 5.89 \%$ (mean of three independent experiments \pm SEM) of worms moved freely without any stimuli (level 1) and $29.4 \pm 5.89 \%$ of worms only moved in response to a mechanical stimulus (level 2) in the wild-type control group. However, SAC treatment significantly altered the ratio of level 1 and level 2; $96.2 \pm 1.52 \%$ of worms were classified as "level 1 " and only $3.8 \pm 1.52 \%$ of worms were in "level 2 " in the SAC-treated worms $(p=0.014)$ (Fig. 5). At the age of 15 days, $23.8 \pm 10.99$ and $65.7 \pm 21.77 \%$ of worms were categorized as "level 1" in wild-type control and SAC-treated worms, respectively. On day 20, worms in "level 1" increased from only 1.9 $\pm 1.85 \%$ in wild-type control to $10.6 \pm 8.53 \%$ in SAC-treated worms (Fig. 5). A recent study shows that ROS-scavenging sesn-1 gene modulates both response to oxidative stress and motility in $C$. elegans (YANG et al., 2013). Deficiency of sesn-1 results in reduced survival under oxidative-stress conditions and decreased locomotive activity, and over-expression of sesn-1 confers increased body bending activity. Dietary supplementation of the flavanone derivative, silymarin, leads to increased resistance to oxidative stress and locomotion rate (YANG et al., 2013). Based on our findings, we conclude that nutritional intervention with SAC can promote the health span of $C$. elegans via improvement of body muscle function as well as an increase of resistance to environmental stressors. 


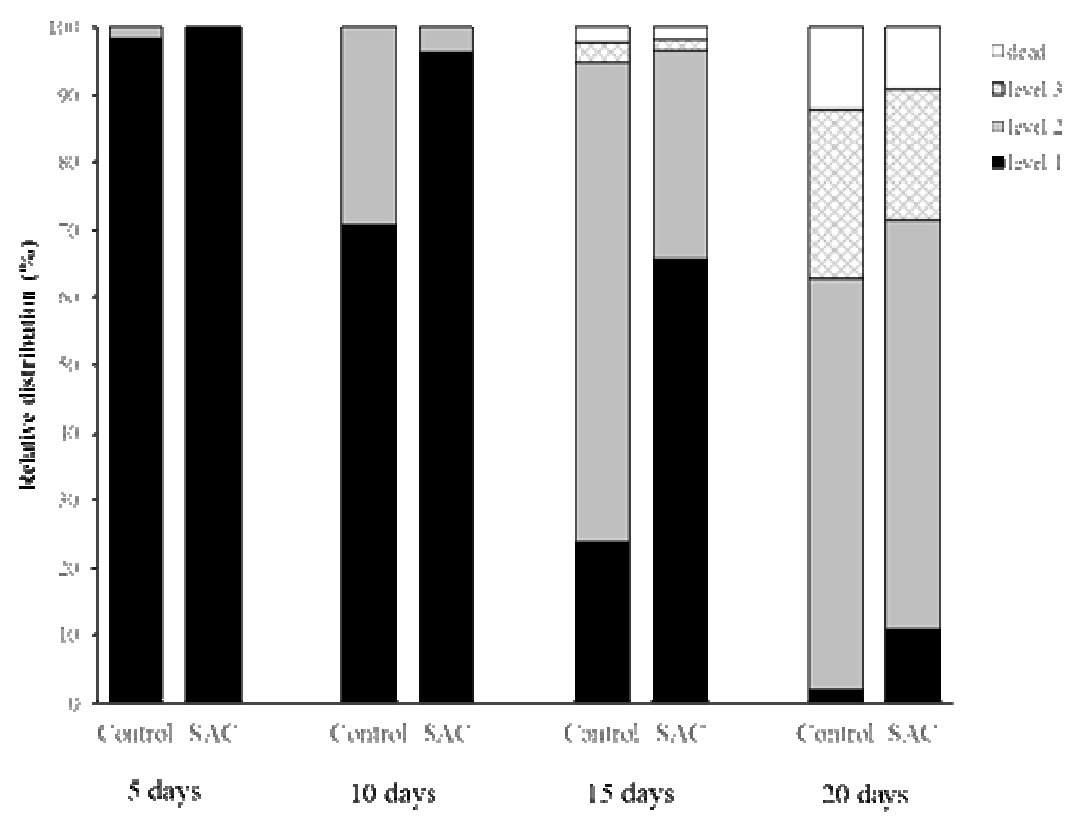

Figure 5. SAC treatment delays muscle dysfunction with aging. Time-course change in motility was determined in the wild-type control and SAC-treated worms. Locomotive activity of each worm was categorized as follows: - level 1, worms move spontaneously without any mechanical stimulus; level 2, worms move whole body when a stimulus was given; 成 level 3, worms move head only in response to a stimulus; $\square$ dead, worms no response to stimulus.

\section{SAC suppresses A $\beta$ toxicity in an Alzheimer's disease (AD) animal model}

$\mathrm{AD}$ is an age-related neurodegenerative disease whose pathogenesis is associated with the accumulation of senile plaques composed of $A \beta$ in the brain (KAYED et al., 2003). Transgenic animals expressing human $A \beta$ in muscle show a paralysis phenotype. Induction of the human $\mathrm{A} \beta$ gene in $C$. elegans used as a genetic AD animal model (LINK, 1995). In the present study, we determined the effects of SAC supplementation on paralysis induced by the $\mathrm{A} \beta$ transgene. As shown in Fig. 6, the dietary supplementation of SAC significantly suppressed paralysis caused by the expression of $A \beta$ in muscle $(p=0.006)$. At $8 \mathrm{~h}$ after $\mathrm{A} \beta$ induction, $41.7 \%$ of the wild-type worms were paralyzed and only $15.0 \%$ of worms treated with SAC were paralyzed. After $11 \mathrm{~h}$ of $\mathrm{A} \beta$ induction, $83.3 \%$ of worms were paralyzed in the wild-type control group, while $48.3 \%$ of worms were still not paralyzed in SAC-treated group (Fig. O). The percent SAC effect on paralysis, calculated using the time taken for $50 \%$ of the worms to become paralyzed in each group, was $18.2 \%$. The replicative experiment also showed a significant suppressive effect of SAC on A $\beta$-induced paralysis ( $p=0.041$, $20.2 \%$ effect, data not shown). Using the same $C$. elegans genetic AD animal model, an insulin/IGF-1like signal modulates anti-oxidative responses and lifespan and ameliorates toxicity caused by the human A $\beta$ transgene (COHEN et al., 2006). Supplementation of tetracycline significantly retards paralysis by the expression of $A \beta$ (DIOMEDE et al., 2010). These findings suggest that SAC has preventive activity against $A \beta$ toxicity and can be a strong candidate compound for the development of therapeutic agents for AD. Further studies focusing on the identification of other bioactivities of SAC and other cysteine derivatives, and development of novel cysteine derivatives containing increased bioactivity and stability are necessary to apply cysteine derivatives to pharmaceutical and medical use. 


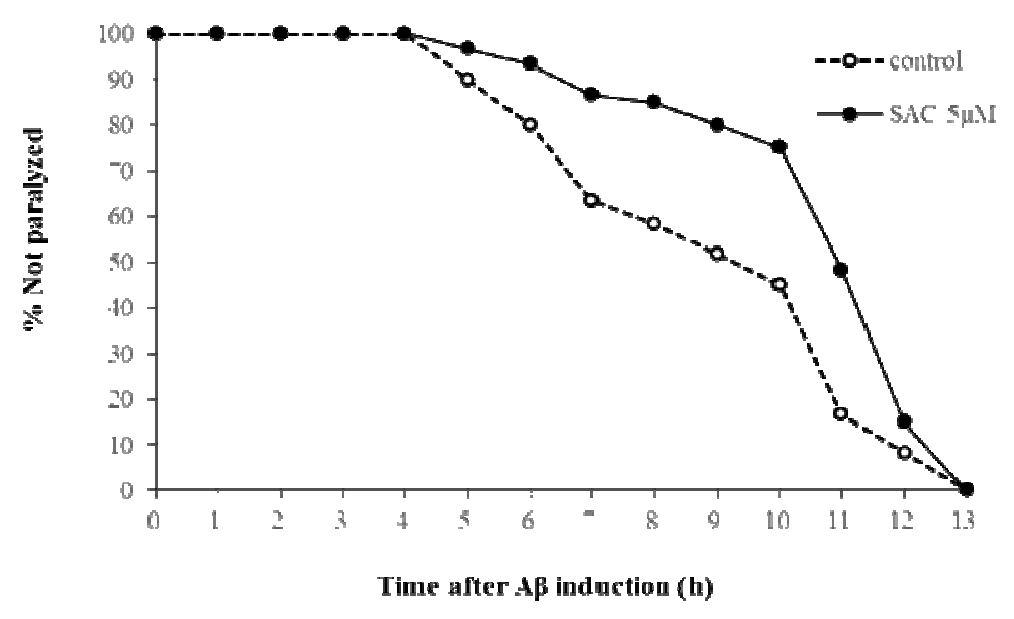

Figure 6. Suppression of $A \beta$-induced toxicity by SAC. The human $A \beta$ transgene was expressed in C. elegans muscle tissues. Induced expression of the $A \beta$ transgene led to paralysis in worms. Supplementation of SAC partially suppresses the onset of $A \beta$-induced paralysis in the AD animal model. The values are mean of three independent experiments.

\section{ACKNOWLEDGEMENTS}

This work was supported by the Soonchunhyang University Research Fund and the
Basic Science Research Program through the National Research Foundation of Korea funded by the Ministry of Education (2015R1D1A1A01057435).

RESUMO: Estudos anteriores mostram que intervenções nutricionais com antioxidantes têm vários efeitos promotores da saúde em vários organismos-modelo. Aqui, examinamos os efeitos da S-alil cisteína sobre a resistência a estressores ambientais e alterações fisiológicas relacionadas com a idade usando C. elegans como um sistema modelo. Salil cisteína é um aminoácido modificado encontrado em extratos de alho envelhecido e conhecido por ter forte atividade antioxidante. A sobrevivência de vermes sob condições de estresse oxidativo aumentou significativamente com a suplementação de S-alil cisteína. Além disso, o pré-tratamento com S-alil cisteína aumentou significativamente a resistência tanto ao estresse térmico como à irradiação ultravioleta. No entanto, o tempo de vida não foi afetado pelo tratamento com S-alil cisteína. Nós também examinamos o efeito da S-alil cisteína na motilidade de C. elegans e descobrimos que a $\mathrm{S}$-alil cisteína pode retardar o declínio relacionado à idade da atividade locomotora do tecido muscular. A S-alil cisteína também suprimiu significativamente a paralisia induzida por amilóide $\beta$ em animais-modelo da doença de Alzheimer. Tomados em conjunto, o nosso estudo indica que a suplementação dietética de S-alil cisteína pode melhorar a duração da saúde e sugere que S-alil cisteína pode ser usada para desenvolver novos produtos farmacêuticos de promoção da saúde.

PALAVRAS-CHAVE: S-alil cisteína. C. elegans. Duração da saúde. Motilidade. Aß-toxicidade.

\section{REFERENCES}

ALLISON, G. L.; LOWE, G. M.; RAHMAN, K. Aged garlic extract and its constituents inhibit platelet aggregation through multiple mechanisms. The Journal of Nutrtion, v. 136, n. 3 Suppl, p. 782S-788S. Mar. 2006.

BAYNE, A. C.; SOHAL, R. S. Effects of superoxide dismutase/catalase mimetics on life span and oxidative stress resistance in the housefly, Musca domestica. Free Radical Biology and Medicine, v. 32, n. 11, p. 12291234. Jun. 2002. https://doi.org/10.1016/S0891-5849(02)00849-3

COHEN, E.; BIESCHKE, J.; PERCIAVALLE, R. M.; KELLY, J. W.; DILLIN, A. Opposing activities protect against age-onset proteotoxicity. Science, v. 313, n. 5793, p. 1604-1610. Sep. 2006.

https://doi.org/10.1126/science.1124646 
COLIN-GONZALEZ, A. L.; ALI, S. F.; TUNEZ, I.; SANTAMARIA, A. On the antioxidant, neuroprotective and anti-inflammatory properties of S-allyl cysteine: An update. Neurochemistry International, v. 89, p. 8391. Oct. 2015. https://doi.org/10.1016/j.neuint.2015.06.011

COLIN-GONZALEZ, A. L.; SANTANA, R. A.; SILVA-ISLAS, C. A.; CHANEZ-CARDENAS, M. E.; SANTAMARIA, A.; MALDONADO, P. D. The antioxidant mechanisms underlying the aged garlic extractand S-allylcysteine-induced protection. Oxidative Medicine and Cellular Longevity, v. 2012, p. 907162. May 2012. https://doi.org/10.1155/2012/907162

DIOMEDE, L.; CASSATA, G.; FIORDALISO, F.; SALIO, M.; AMI, D.; NATALELLO, A.; DOGLIA, S. M.; DE LUIGI, A.; SALMONA, M. Tetracycline and its analogues protect Caenorhabditis elegans from beta amyloid-induced toxicity by targeting oligomers. Neurobiology of Disease, v. 40, n. 2, p. 424-431. Nov. 2010. https://doi.org/10.1016/j.nbd.2010.07.002

FERGUSON, L. R. Role of plant polyphenols in genomic stability. Mutation Research, v. 475, n. 1-2, p. 89111. Apr. 2001. https://doi.org/10.1016/S0027-5107(01)00073-2

FUKUI, K.; OMOI, N. O.; HAYASAKA, T.; SHINNKAI, T.; SUZUKI, S.; ABE, K.; URANO, S. Cognitive impairment of rats caused by oxidative stress and aging, and its prevention by vitamin E. Annals of the New York Academy of Sciences, v. 959, p. 275-284. Apr. 2002. https://doi.org/10.1111/j.1749-6632.2002.tb02099.x

GRUNZ, G.; HAAS, K.; SOUKUP, S.; KLINGENSPOR, M.; KULLING, S. E.; DANIEL, H.; SPANIER, B. Structural features and bioavailability of four flavonoids and their implications for lifespan-extending and antioxidant actions in C. elegans. Mechanisms of Ageing and Development, v. 133, n. 1, p. 1-10. Jan. 2012. https://doi.org/10.1016/j.mad.2011.11.005

HERMAN, D. Aging: a theory based on free radical and radiation chemistry. Journal of Gerontology, v. 11, $\mathrm{n}$. 3, p. 298-300. Jul. 1956. https://doi.org/10.1093/geronj/11.3.298

IDE, N.; LAU, B. H. Garlic compounds minimize intracellular oxidative stress and inhibit nuclear factor-kappa b activation. The Journal of Nutrition, v. 131, n. 3s, p. 1020S-1026S. Mar. 2001.

JANG, M.; CAI, L.; UDEANI, G. O.; SLOWING, K. V.; THOMAS, C. F.; BEECHER, C. W.; FONG, H. H.; FARNSWORTH, N. R.; KINGHORN, A. D.; MEHTA, R. G.; MOON, R. C.; PEZZUTO, J. M. Cancer chemopreventive activity of resveratrol, a natural product derived from grapes. Science, v. 275, n. 5297, p. 218 220. Jan. 1997. https://doi.org/10.1126/science.275.5297.218

KAYED, R.; HEAD, E.; THOMPSON, J. L.; MCINTIRE, T. M.; MILTON, S. C.; COTMAN, C. W.; GLABE, C. G. Common structure of soluble amyloid oligomers implies common mechanism of pathogenesis. Science, v. 300, n. 5618, p. 486-489. Apr. 2003. https://doi.org/10.1126/science.1079469

KITANI, K.; YOKOZAWA, T.; OSAWA, T. Interventions in aging and age-associated pathologies by means of nutritional approaches. Annals of the New York Academy of Sciences, v. 1019, p. 424-426. Jun. 2004. https://doi.org/10.1196/annals.1297.075

LAI, C. H.; CHOU, C. Y.; CHANG, L. Y.; LIU, C. S.; LIN, W. C. Identification of novel human genes evolutionarily conserved in Caenorhabditis elegans by comparative proteomics. Genome Research, v. 10, n. 5, p. 703-713. May 2000. https://doi.org/10.1101/gr.10.5.703

LARSEN, P. L. Aging and resistance to oxidative damage in Caenorhabditis elegans. Proceedings of the National Academy of Sciences of the United States of America, v. 90, n. 19, p. 8905-8909. Oct. 1993. https://doi.org/10.1073/pnas.90.19.8905 
LEE, C. K.; ALLISON, D. B.; BRAND, J.; WEINDRUCH, R.; PROLLA, T. A. Transcriptional profiles associated with aging and middle age-onset caloric restriction in mouse hearts. Proceedings of the National Academy of Sciences of the United States of America, v. 99, n. 23, p. 14988-14993. Nov. 2002. https://doi.org/10.1073/pnas.232308999

LINK, C. D. Expression of human beta-amyloid peptide in transgenic Caenorhabditis elegans. Proceedings of the National Academy of Sciences of the United States of America, v. 92, n. 20, p. 9368-9372. Sep. 1995. https://doi.org/10.1073/pnas.92.20.9368

MALDONADO, P. D.; BARRERA, D.; RIVERO, I.; MATA, R.; MEDINA-CAMPOS, O. N.; HERNANDEZPANDO, R.; PEDRAZA-CHAVERRI, J. Antioxidant S-allylcysteine prevents gentamicin-induced oxidative stress and renal damage. Free Radical Biology and Medicine, v. 35, n. 3, p. 317-324. Aug. 2003. https://doi.org/10.1016/S0891-5849(03)00312-5

MILGRAM, N. W.; HEAD, E.; MUGGENBURG, B.; HOLOWACHUK, D.; MURPHEY, H.; ESTRADA, J.; IKEDA-DOUGLAS, C. J.; ZICKER, S. C.; COTMAN, C. W. Landmark discrimination learning in the dog: effects of age, an antioxidant fortified food, and cognitive strategy. Neuroscience and Biobehavioral Reviews, v. 26, n. 6, p. 679-695. Oct. 2002. https://doi.org/10.1016/S0149-7634(02)00039-8

MORIHARA, N.; SUMIOKA, I.; IDE, N.; MORIGUCHI, T.; UDA, N.; KYO, E. Aged garlic extract maintains cardiovascular homeostasis in mice and rats. The Journal of Nutrition, v. 136, n. 3 Suppl, p. 777S-781S. Mar. 2006.

NAVARRO, A.; GOMEZ, C.; SANCHEZ-PINO, M. J.; GONZALEZ, H.; BANDEZ, M. J.; BOVERIS, A. D.; BOVERIS, A. Vitamin $\mathrm{E}$ at high doses improves survival, neurological performance, and brain mitochondrial function in aging male mice. American Journal of Physiology. Regulatory, Integrative, and Comparative Physiology, v. 289, n. 5, p. R1392-R1399. Nov. 2005. https://doi.org/10.1152/ajpregu.00834.2004

OGAWA, T.; KODERA, Y.; HIRATA, D.; BLACKWELL, T. K.; MIZUNUMA, M. Natural thioallyl compounds increase oxidative stress resistance and lifespan in Caenorhabditis elegans by modulating SKN1/Nrf. Scientific Reports, v. 6, p. 21611. Feb. 2016. https://doi.org/10.1038/srep21611

OH, S. I.; PARK, J. K.; PARK, S. K. Lifespan extension and increased resistance to environmental stressors by N-acetyl-L-cysteine in Caenorhabditis elegans. Clinics (Sao Paulo), v. 70, n. 5, p. 380-386. May 2015. https://doi.org/10.6061/clinics/2015(05)13

PARK, J. K.; KIM, C. K.; GONG, S. K.; YU, A. R.; LEE, M. Y.; PARK, S. K. Acanthopanax sessiliflorus stem confers increased resistance to environmental stresses and lifespan extension in Caenorhabditis elegans.

Nutrition Research and Practice, v. 8, n. 5, p. 526-532. Oct. 2014. https://doi.org/10.4162/nrp.2014.8.5.526

PARK, S. K.; KIM, J. J.; YU, A. R.; LEE, M. Y.; PARK, S. K. Electrolyzed-reduced water confers increased resistance to environmental stresses. Molecular and Cellular Toxicology, v. 8, p. 241-247. Sep. 2012. https://doi.org/10.1007/s13273-012-0029-1

PARK, S. K.; PARK, S. K. Electrolyzed-reduced water increases resistance to oxidative stress, fertility, and lifespan via insulin/IGF-1-like signal in C. elegans. Biological Research, v. 46, n. 2, p. 147-152. 2013. https://doi.org/10.4067/S0716-97602013000200005

PENG, Q.; BUZZZARD, A. R.; LAU, B. H. Neuroprotective effect of garlic compounds in amyloid-beta peptide-induced apoptosis in vitro. Medical Science Monitor, v. 8, n. 8, p. BR328-BR337. Aug. 2002. 
PEREZ-SEVERIANO, F.; SALVATIERRA-SANCHEZ, R.; RODRIGUEZ-PEREZ, M.; CUEVASMARTINEZ, E. Y.; GUEVARA, J.; LIMON, D.; MALDONADO, P. D.; MEDINA-CAMPOS, O. N.; PEDRAZA-CHAVERRÍ, J.; SANTAMARIA, A. S-Allylcysteine prevents amyloid-beta peptide-induced oxidative stress in rat hippocampus and ameliorates learning deficits. European Journal of Pharmacology, v. 489, n. 3, p. 197-202. Apr. 2004. https://doi.org/10.1016/j.ejphar.2004.03.001

PETO, R.; PETO, J. Asymptotically efficient rank invariant test procedures. Journal of the Royal Statistical Society: Series A, v. 135, n. 2, p. 185-207. 1972. https://doi.org/10.2307/2344317

RISTOW, M.; SCHMEISSER, K. Mitohormesis: Promoting health and lifespan by increased levels of reactive oxygen species (ROS). Dose Response, v. 12, n. 2, p. 288-341. Jan. 2014. https://doi.org/10.2203/doseresponse.13-035.Ristow

ROSENFELDT, F. L.; PEPE, S.; LINNANE, A.; NAGLEY, P.; ROWLAND, M.; OU, R.; MARASCO, S.; LYON, W.; ESMORE, D. Coenzyme Q10 protects the aging heart against stress: studies in rats, human tissues, and patients. Annals of the New York Academy of Sciences, v. 959, p. 355-359. Apr. 2002.

https://doi.org/10.1111/j.1749-6632.2002.tb02106.x

SHI, H.; JING, X.; WEI, X.; PEREZ, R. G.; REN, M.; ZHANG, X.; LOU, H. S-allyl cysteine activates the Nrf2-dependent antioxidant response and protects neurons against ischemic injury in vitro and in vivo. Journal of Neurochemistry, v. 133, n. 2, p. 298-308. Apr. 2015. https://doi.org/10.1111/jnc.12986

SINGH, F.; CHARLES, A. L.; SCHLAGOWSKI, A. I.; BOUITBIR, J.; BONIFACIO, A.; PIQUARD, F.; KRÄHENBÜHL, S.; GENY, B.; ZOLL, J. Reductive stress impairs myoblasts mitochondrial function and triggers mitochondrial hormesis. Biochimica et Biophysica Acta, v. 1853, n 7, p. 1574-1585. Jul. 2015. https://doi.org/10.1016/j.bbamcr.2015.03.006

SUH, J. H.; SHIGENO, E. T.; MORROW, J. D.; COX, B.; ROCHA, A. E.; FREI, B.; HAGEN, T. M. Oxidative stress in the aging rat heart is reversed by dietary supplementation with (R)-(alpha)-lipoic acid. Federation of American Societies for Experimental Biology Journal, v. 15, n. 3, p. 700-706. Mar. 2001.

https://doi.org/10.1096/fj.00-0176com

WOOD, J. G.; ROGINA, B.; LAVU, S.; HOWITZ, K.; HELFAND, S. L.; TATAR, M.; Sinclair, D. Sirtuin activators mimic caloric restriction and delay ageing in metazoans. Nature, v. 430, n. 7000, p. 686-689. Aug. 2004. https://doi.org/10.1038/nature02789

YANG, Y. L.; LOH, K. S.; LIOU, B. Y.; CHU, I. H.; KUO, C. J.; CHEN, H. D.; CHEN, C. S. (2013). SESN-1 is a positive regulator of lifespan in Caenorhabditis elegans. Experimental Gerontology, v. 48, n. 3, p. 371-379. Mar. 2013. https://doi.org/10.1016/j.exger.2012.12.011 